\title{
The reproductive biology of Lutraria philippinarum (Veneroida: Mactridae) and its fishery in the Philippines
}

\author{
Venus Bantoto ${ }^{1,2} \&$ Anthony Ilano ${ }^{1}$ \\ 1. Biology Department, University of San Carlos, Nasipit, Talamban,6000 Cebu, Philippines; gastropoda04@yahoo.com \\ 2. Biology Department, Negros Oriental State University, Kagawasan Avenue, 6200 Dumaguete City, Negros Oriental, \\ Philippines; vdbbio@yahoo.com
}

Received 11-X-2011. Corrected 03-IV-2012. Accepted 08-V-2012.

\begin{abstract}
The Snout Otter Clam, Lutraria philippinarum is a regularly harvested bivalve species for food and also as a source of income in the Philippines. For sustainable supply of this resource in the wild, efficient and effective management strategies are needed, and the evaluation of its reproductive biology and fishery are required. In this study, the reproductive biology and fishery of L. philippinarum in the Philippines were examined monthly from January to December 2010 in North Bais Bay, Manjuyod, Negros Oriental and Philippines. For reproductive biology, otter clams were sampled, and sex ratio (by microscopic observation), size at sexual maturity, shell length (with a vernier caliper), gonad development (by histological examination as resting, developing, mature, spawning and spent) and spawning season were determined. Other information such as water temperature, salinity, $\mathrm{pH}$ and dissolved oxygen were also measured. To obtain information on the L. philippinarum fishery, interviews were conducted in Negros Oriental, Bohol, Cebu and Sarangani. A total of 677 snout otter clams were sampled. The study showed that L. philippinarum sex ratio was 1:1.15 and showed no significant difference from 1:1 ratio. Males attained its first sexual maturity at $43 \mathrm{~mm}$ shell length while the females at $46 \mathrm{~mm}$. Histological examination on gonad development indicated that gametogenesis, maturation and spawning season of $L$. philippinarum occurred throughout the year with two spawning peaks, January and June. Changes in water temperature in North Bais Bay may have influenced the spawning peaks of L. philippinarum. Data on the fishery of L. philippinarum revealed that the Catch Per Unit Effort of L. philippinarum in the Philippines ranged from $0.2 \mathrm{~kg} / \mathrm{hr}$-man to $1.25 \mathrm{~kg} / \mathrm{hr}$-man suggesting low shell catch. We recommend that some mature individuals have to be left in the population to allow in situ breeding. Rev. Biol. Trop. 60 (4): 1807-1818. Epub 2012 December 01.
\end{abstract}

Key words: Lutraria philippinarum, sexual maturity, spawning, sex ratio, fishery.

Lutraria philippinarum, (Deshayes 1854) commonly known as snout otter clam is a bivalve that occurs in the Philippines, Thailand, China, Australia and Vietnam (Ha Duc Dang et al. 2006). According to Ha Duc Dang et al. (2006), it is one of the commercially utilized species in Vietnam as it becomes highly in demand in restaurants. In the Philippines, L. philippinarum is regularly harvested for food and source of income. The uncontrolled and regular harvesting of this resource may eventually lead to population decline in the wild; as observed in other economically important marine species in the Philippines such as Anadara, Modiolus, Crassostrea, Placuna, Phacoides, Periglypta, Tapes, Mactra and Haliotis (Luchavez \& Abrenica 1997), Strombus (Ciasico et al. 2006) and Paphia textilis (Ilano et al. 2007). In the case of L. philippinarum, anecdotal reports in the Philippines revealed that the mean size harvested is getting smaller through time, an indication of recruitment overfishing which eventually will lead to population decline. With this situation, an efficient management approach to L. philippinarum is needed to ensure sustainable production in the future. However, before any management 
measures can be implemented, information on population density of the resource as well as knowledge on the reproductive biology should be undertaken (Gosling 2003, Ilano et al. 2007).

Lack of information on the biology of the exploited bivalves is one of the main problems in the tropical regions (Mzighani 2005). In the Philippines setting, no study has been done yet on L. philippinarum in whatever aspect. Thus, this study aimed to give baseline information on the reproductive biology of L. philippinarum specifically on the size at sexual maturity, sex ratio, gonad development and spawning season. Moreover, some information about the fishery of L. philippinarum in the Philippines such as volume of catch and catch per unit effort which are needed for efficient and sustainable management strategies were also noted.

\section{MATERIALS AND METHODS}

Reproductive biology: A total of 677 clams were collected from January to December 2010 directly from the sampling site in
North Bais Bay, Manjuyod, Negros Oriental, Philippines $\left(9^{\circ} 38^{\prime} \mathrm{N}-123^{\circ} 08^{\prime}\right.$ E) (Fig. 1), by skin diving and handpicking during daytime when the siphons of the organisms were very visible. From 677 clam samples collected, 27 individuals were collected in January, 37 in February, 48 in March, 62 in April, 59 in May, 77 in June, 73 in July, 63 in August, 52 in September, 63 in October, 53 in November and 63 in December, respectively. Each sample was examined histologically to determine the sex ratio, size at sexual maturity and gonad development. The sex of the clam was determined from each gonad under a compound microscope. The presence of seminal vesicle containing hairlike spermatozoa in the gonad indicated a male clam, while the presence of follicles with oogonia or polygonal shaped oocytes indicated a female clam. Sex ratio was calculated by dividing the number of female individuals by the number of male individuals. Chi-square test was applied to test whether the population adheres to 1:1 ratio (Ilano et al. 2007). For size at sexual maturity, all samples were measured

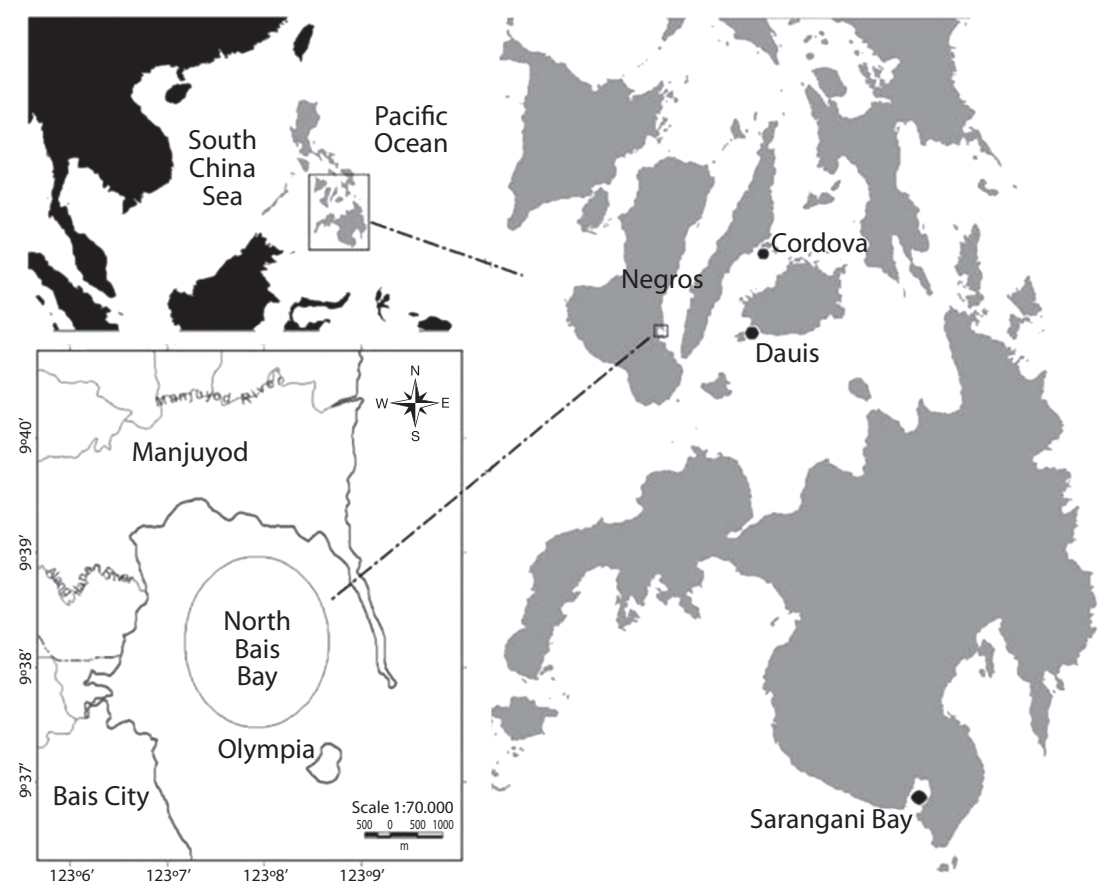

Fig. 1. The collection sites of snout otter clam, Lutraria philippinarum in the Philippines. 
in millimeter $(\mathrm{mm})$ using a vernier caliper and the shortest shell length in which the gonad contained gametes was considered as the size at first sexual maturity.

The stages of gonad development were classified by observing sections under the compound microscope as resting, developing, mature, spawning and spent (Ilano et al. 2007). The reproductive condition of the clam during this study was quantified using a Gonad Index (Hightower \& Grossman 1985). The Gonad Index for each sampling was calculated following the formula used by Ilano et al. 2007. The formula is written as follows:

$$
\mathrm{GI}=\sum \frac{\mathrm{nxW}}{\mathrm{N}}
$$

where, $\mathrm{n}=$ number of individuals in a given developmental stage

$\mathrm{N}=$ total number of individuals/ monthly sample and

$\mathrm{W}=$ the pre-weighed value for the developmental stage

The assigned pre-weighed value for resting and spent stages is 1, 2 for developing and spawning and 3 for mature stages. Water temperature, salinity, $\mathrm{pH}$ and dissolved oxygen in North Bais Bay that may affect the gonad development of L. philippinarum were also measured monthly in the sampling site using thermometer, refractometer and DO meter, respectively. The effects were determined using One-way ANOVA at $95 \%$ confidence level.

Fishery: The status of the fishery of $L$. philippinarum in the country was determined by conducting interviews to the collectors in identified collecting sites, using a prepared survey questionnaire (Appendix). Some of the information that were asked from the respondents were: the volume of catch per trip per collector, method of collection and economic importance of the clam to the fisherfolks whether it could be their source of income as well. The respondents were also asked to compare the volume of catch before; approximately 5-10 years ago and the present. The interviews were done in Manjuyod, Negros Oriental ( $\left.9^{\circ} 38^{\prime} \mathrm{N}-123^{\circ} 08^{\prime} \mathrm{E}\right)$; Dauis, Bohol (9'37'31' N - 12305'57' E); Cordova, Cebu $\left(10^{\circ} 15^{\prime} \mathrm{N}-123^{\circ} 57^{\prime} \mathrm{E}\right)$ and Glan, Sarangani $\left(6^{\circ} 07^{\prime} \mathrm{N}-125^{\circ} 06^{\prime \prime}\right.$ E) (Fig. 1). There were forty one respondents in this study which were distributed as follows: sixteen collectors from Cordova, Cebu, fifteen from Manjuyod, Negros Oriental, five from Dauis, Bohol and five from Glan, Sarangani.

The Catch Per Unit Effort (CPUE) was determined using the daily total catch data as total weight in kilograms and daily fishing time spend for each collector. CPUE was computed using the formula:

$$
\text { CPUE }=\frac{\text { Total weight of catch }(\mathrm{kg})}{\text { Total fishing time }(\mathrm{hr}) \text { per collector }(\mathrm{man})}
$$

\section{RESULTS}

Reproductive biology: Based on the histological examination of 677 clam samples, it was found out that L. philippinarum is dioecious and the overall female: male ratio was $1: 1.15$. The percentage of male clams was more than that of the female in all months of the year except in February and December. The highest difference in the percentage of males and females was observed in March (Fig. 2). However, Chi-square test showed that the sex ratio of $L$. philippinarum did not depart from $1: 1$ ratio $\left(x^{2}=2, d f=1, p>0.05\right)$.

The monthly size distribution and sexual maturity of $L$. philippinarum is shown in Table 1. The size of $L$. philippinarum was concentrated at $61-105 \mathrm{~mm}$. All clams sampled were sexually matured. However, males were observed to mature earlier at $43 \mathrm{~mm}$ than females which matured at $46 \mathrm{~mm}$.

The gonad stages of L. philippinarum that were observed in this study were developing, mature, spawning and spent stages (Fig. 3). In developing stage, the highest percentage was recorded in February at $94 \%$ in males and $71 \%$ in females. In March to June, there was a gradual decrease in the percentage of clams for both male and female $(78-11 \%$ in males; $45-26 \%$ in 
TABLE 1

Monthly length size distribution and sexual maturity of snout otter clam, Lutraria philippinarum

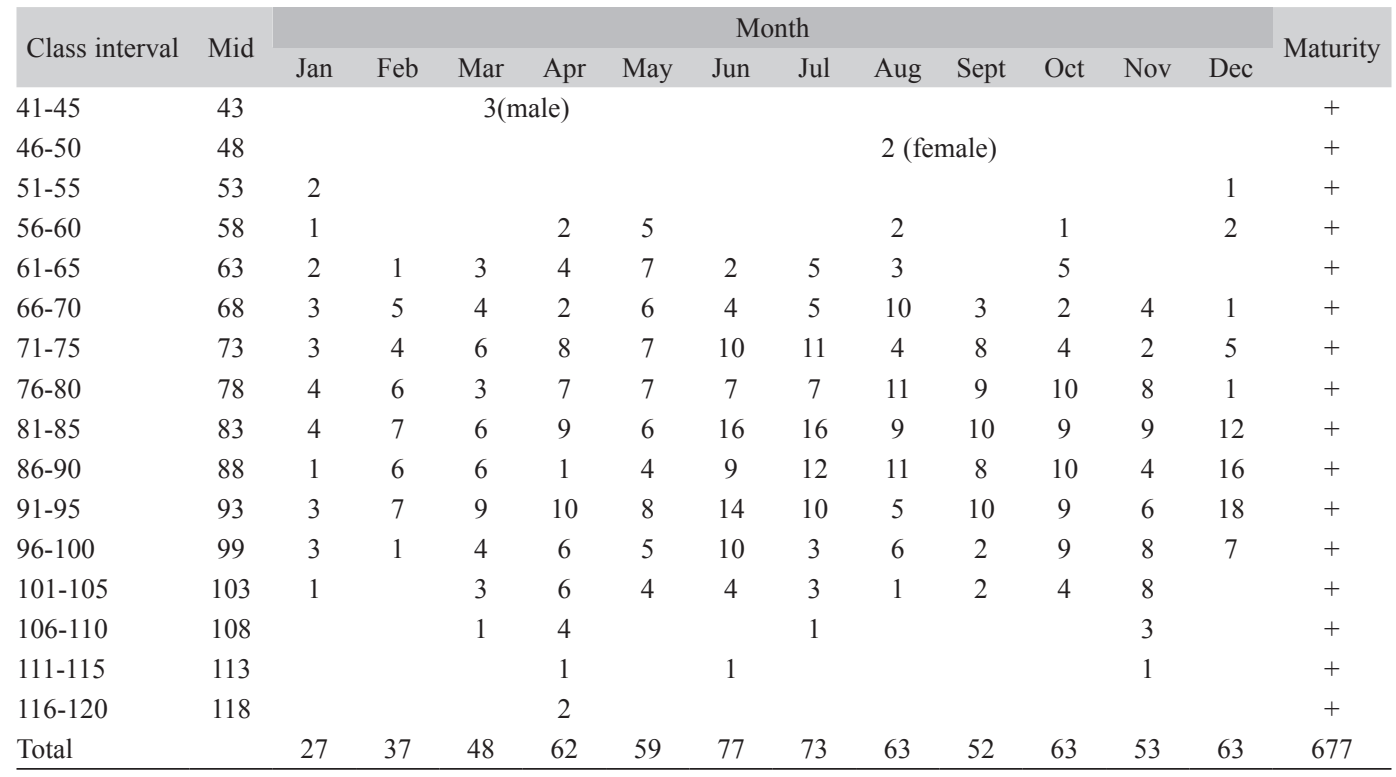

$+=$ sexually matured.

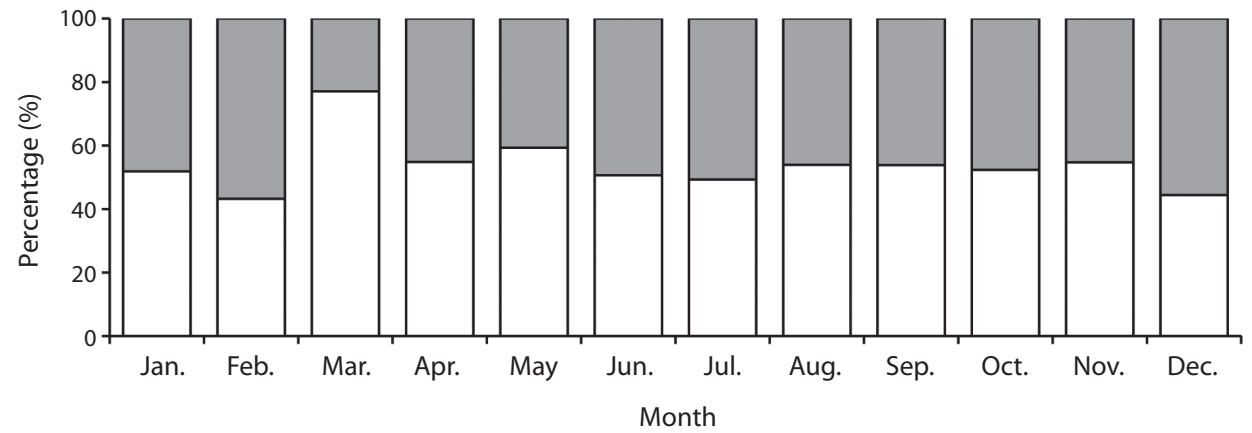

Fig. 2. Sex distribution of snout otter clam, Lutraria philippinarum from North, Bais Bay, Manjuyod, Negros Oriental, Philippines.

females). In July until September, a marked increase in the percentage of clams especially in males (15-82\%) was observed. Towards the end of the year, from October to December the percentage decreased again for both male and female (70-52\% in males; $43-29 \%$ in females).
Unlike in developing stages, the percentage of clams with matured gonads was lowest in February at $6 \%$ in male and $29 \%$ in female. On the other hand, matured male clams were observed high in January, June, July and November. For females, the percentage was 

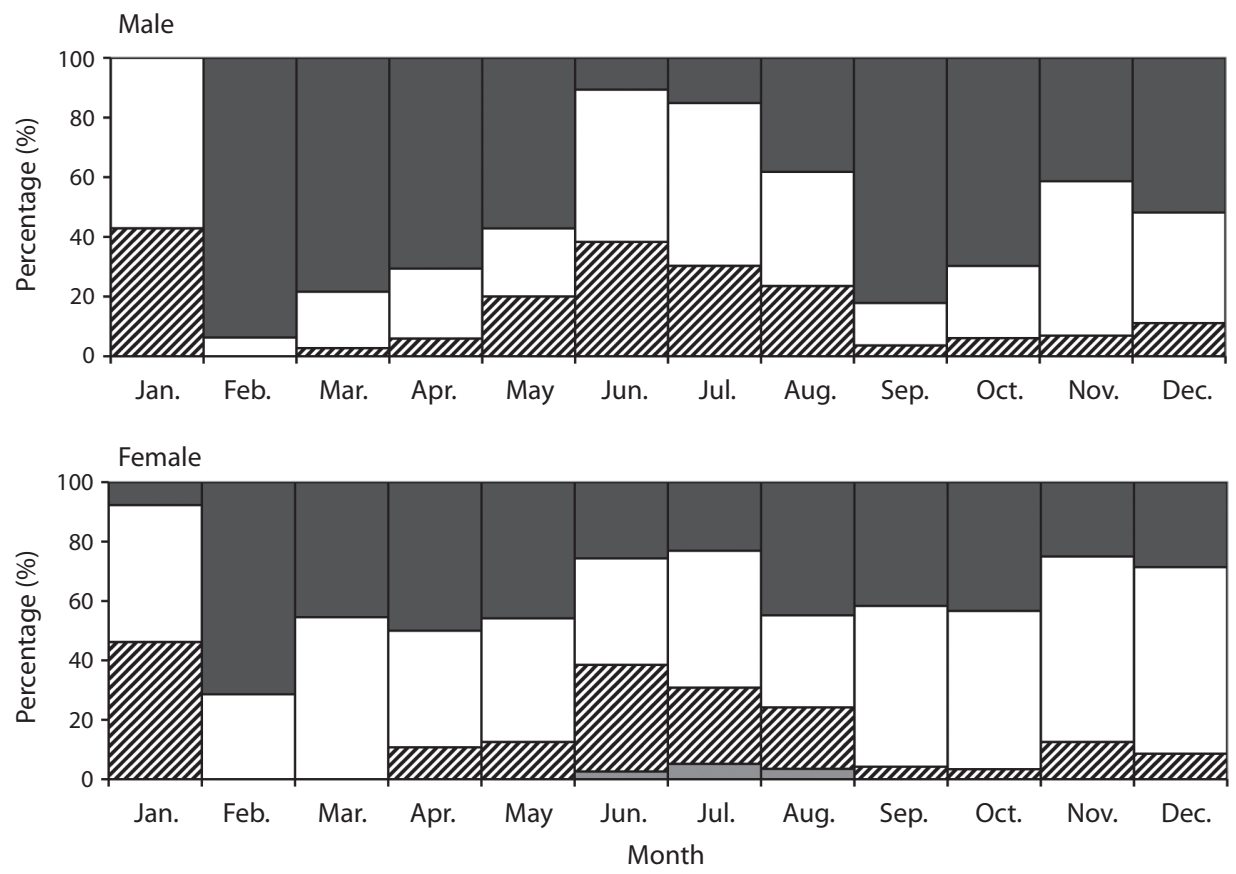

口Developing $\square$ Mature $\boldsymbol{\square}$ Spawning $\square$ Spent

Fig. 3. The monthly frequency distribution of the stages of gonad development of male and female snout otter clam, Lutraria philippinarum . developing $=$ dark gray; mature $=$ white; spawning $=$ diagonal lines; $\mathbf{s p e n t}=$ light gray .

high in most months of the year. Over a year, gonads in mature stage were present in both male and female L. philippinarum.

In the case of spawning stage, clams with spawning gonads were observed in most of the months of the year but it was in January (43\% in males, $46 \%$ in females) and June (38\% in males, $36 \%$ in females) when the highest percentage was recorded. L. philippinarum possibly spawned throughout the year with peaks in January and June which could be related to the increase and decrease in water temperature (Fig. 4). During this study, no resting stage was observed in both male and female. Spent stage was not also observed in males while only $3-5 \%$ female with spent gonads were observed in June to August.

Description of the stages of gonad development of Lutraria philippinarum: The identification and description of each stage of the gonad development in both male and female L. philippinarum is based on the five stages categorized by Ilano et al. (2007) in their study on the nailon shell, P. textilis. The five stages are; resting, developing, mature, spawning and spent, shown in figure 5 and are described below:

Stage 1. Resting. During this study, no gonads in resting stage were observed in contrast to what Ilano et al. (2007) observed in $P$. textilis wherein the resting stage was characterized by gonads with indeterminate sex and sometimes the presence of few residual spermatogonia.

Stage 2. Developing (Figures 5A, B and C). During early developing stage, the gonads contained male spermatogonia and female oogonia. In the late developing stage, a number of spermatozoa were present in the seminal vesicle of males. While in females, a number of oogonia decreased 


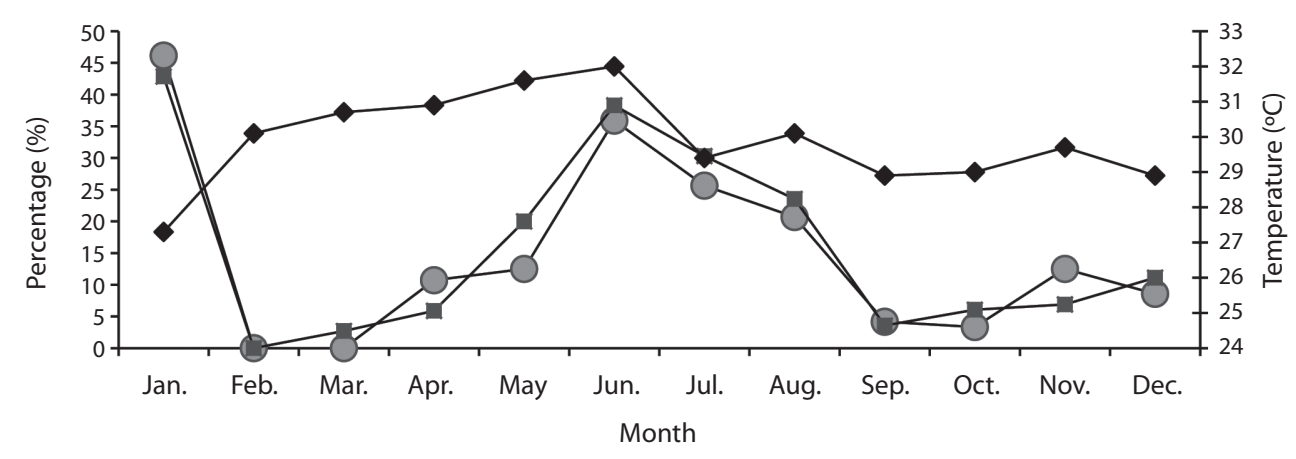

$\rightarrow 0$ Spawning Female $\rightarrow-$ Spawning Male $\rightarrow \bullet-$ Temperature $\left({ }^{\circ} \mathrm{C}\right)$

Fig. 4. Monthly variations in water temperature $\left({ }^{\circ} \mathrm{C}\right)$ in the collecting site and the percentage of Lutraria philippinarum in spawning stage.

and were replaced by a polygonal shaped free oocyte.

Stage 3. Mature (Figures 5D and E). The female and male gonads in this stage were very prominent. The follicles of females were full of free oocytes and the male seminal vesicles were full of spermatozoa that give its gonad a hairy-like structure.

Stage 4. Spawning (Figures 5F and G). The gonads in this stage showed a decrease in the number of gametes and the presence of empty space in the lumen, an indication that spermatozoa and oocytes have been released. In males, a portion of the spermatozoa had been released but there were still remaining active spermatozoa making the lumen to be a little emptier. In females, underdeveloped oogonia remained in the lumen.

Stage 5. Spent (Figures 5H). The gonads were collapsed and irregular in shape with big empty space in the lumen and few germinal cells.

Gonad index: The mean GI values of $L$. philippinarum were higher in January, June and November and lower in February (Fig. 6). High GI values coincided with high percentage of matured clams in January, June and November. Whereas, low GI value in February coincided with the highest percentage of clams in developing stage. For all months of the year, the mean GI values of $L$. philippinarum ranged from 2.2-2.6.

Some physico-chemical parameters off the waters of North Bais Bay: In this study, the water temperature ranged from $27-32^{\circ} \mathrm{C}$, with the minimum of $27^{\circ} \mathrm{C}$ recorded in January and maximum of $32^{\circ} \mathrm{C}$ in June (Fig. 7). The salinity was 35 psu in most of the months throughout the year but decreased by $1 \mathrm{psu}$ in January, September, October and December. The dissolved oxygen ranged from $5.3 \mathrm{mg} / \mathrm{L}$ $7 \mathrm{mg} / \mathrm{L}$ while $\mathrm{pH}$ of the water was alkaline ranging from 7.5-9.

Among the physico-chemical parameters measured, only water temperature showed fluctuation with an increase of $5^{\circ} \mathrm{C}$ from January to June and decrease of $3.1^{\circ} \mathrm{C}$ from June to December. Salinity, $\mathrm{pH}$ and dissolved oxygen had slight fluctuations. Figure 4 showed that spawning peaks could be related to the decrease and increase in water temperature in January and June (ANOVA, $\mathrm{p}<0.05$ ). In January when the water temperature was lowest, there was highest percentage of both male and female clams in spawning stage. When the 


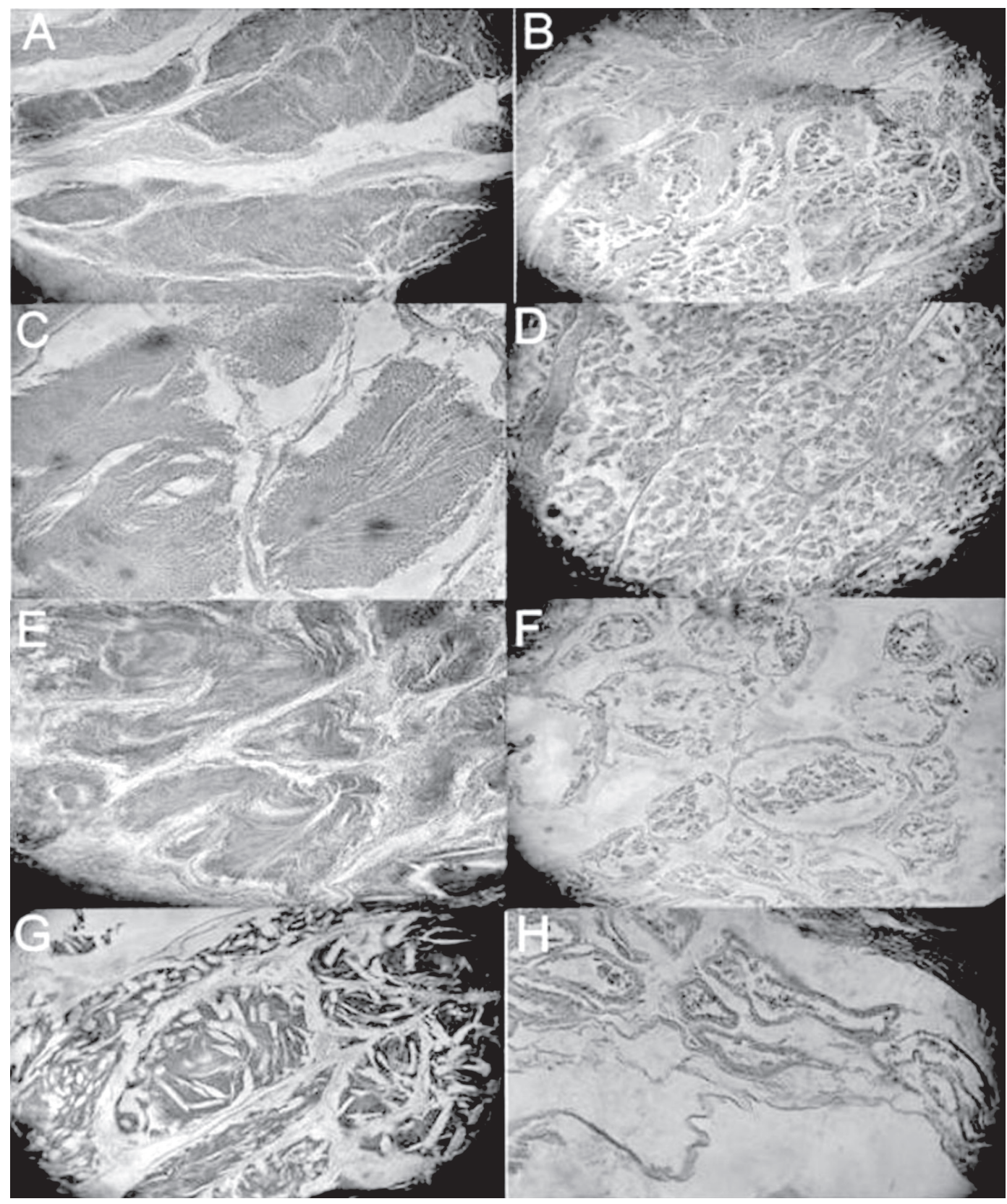

Fig. 5. The different stages of gonad development of Lutraria philippinarum. (A) male (B) female, developing stage; (C) male, late developing stage; (D) female, mature stage; (E) male, mature stage; (F) female, spawning stage; (G) male, spawning stage; $(\mathbf{H})$ female, spent stage (100x magnification). 


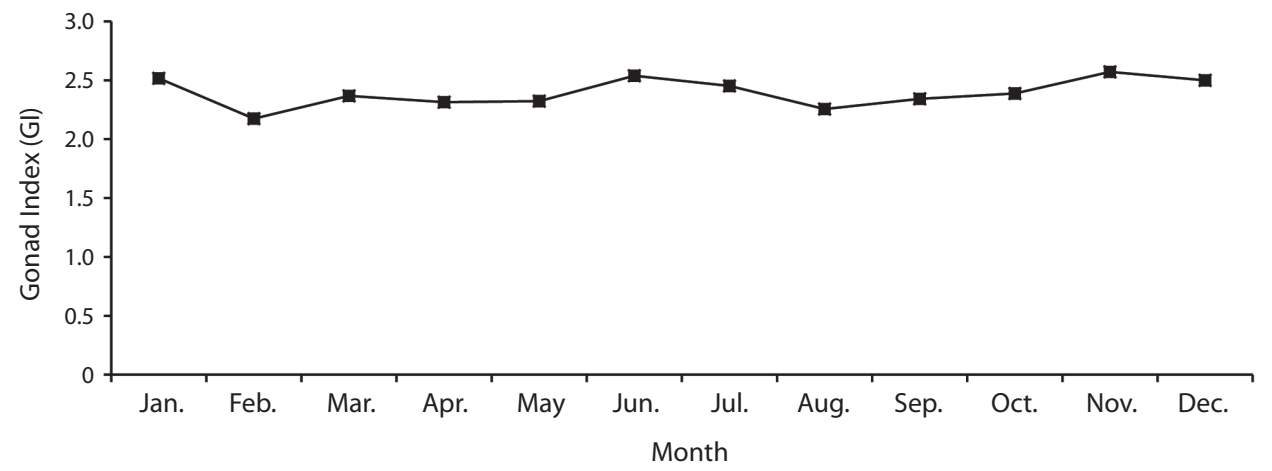

Fig. 6. Monthly variations in the mean Gonad Index (GI) of snout otter clam, Lutraria philppinarum.

water temperature was highest in June, a higher percentage of clams spawned again.

\section{Notes on the fishery of snout otter clam} in the Philippines: L. philippinarum was found in the sandy beaches at a depth range of $1-6 \mathrm{~m}$ and where the water is clear. This species burrowed under the sand and extend its long siphon to the surface for feeding. These siphons of L. philippinarum were used by the collectors to trace the presence of this clam under the sand. The collection of $L$. philippinarum in the Philippines is usually done singly through skin diving and handpicking from 6:00-14:00 $\mathrm{pm}$, with the use of a motor boat. During this time, clam siphons were still visible making the collection easier and faster. Among the sites, it was in Manjuyod where the collection took longer and the volume of catch was higher. Collection took 7-8hr in Manjuyod, 4-10hr in Glan and 4-6hr in Cordova and Bohol. The volume of catch ranged from $1-10 \mathrm{~kg}$ per trip per collector; highest in Manjuyod and lowest in Cordova. The catch was sold by the wives in the local markets of Negros Oriental, Cebu, Bohol and Sarangani at Php60/kg or US\$ 1.42/ $\mathrm{kg}(\mathrm{US} \$ 1=$ Php 42.35 in Jan 2012) some were used as food. The Catch Per Unit Effort (CPUE) of L. philippinarum was highest in Manjuyod at $1.25 \mathrm{~kg} / \mathrm{hr}$-man while lowest in Cordova, Cebu at $0.2 \mathrm{~kg} / \mathrm{hr}-\mathrm{man}$.

\section{DISCUSSION}

Reproductive biology: The number of male and female L. philippinarum in North Bais Bay is still in equilibrium. Hence, eggs from each fecund female have higher chance to be fertilized by males and success in reproduction is assured.

Results of this study showed that female L. philippinarum generally matured late than male. According to Honkoop et al. (1999) bivalve eggs contain large amount of lipids with relatively higher energy content than protein and carbohydrates hence, costly in terms of energy. The use of digestive gland reserves for the reproductive activities in females and not in males is also likely related to the much greater reproductive investment in females such as in the case of B. isaotakii (Ilano et al. 2003). In other species such as Buccinum undatum (Ilano et al. 2003), females need more energy than males because of their need to produce egg capsules. Other factors that caused the differences in size at sexual maturity in both males and females were competition for mates in males, trade off between growth and reproduction, parasitic infection and environmental and fishing pressures (Ilano et al. 2003). In Anadara antiquata, due to their protandrous situation, males have to mature earlier than females to compete for the fertilization of the eggs from the fecund females before they will change their sex to females (Mzighani 2005). 

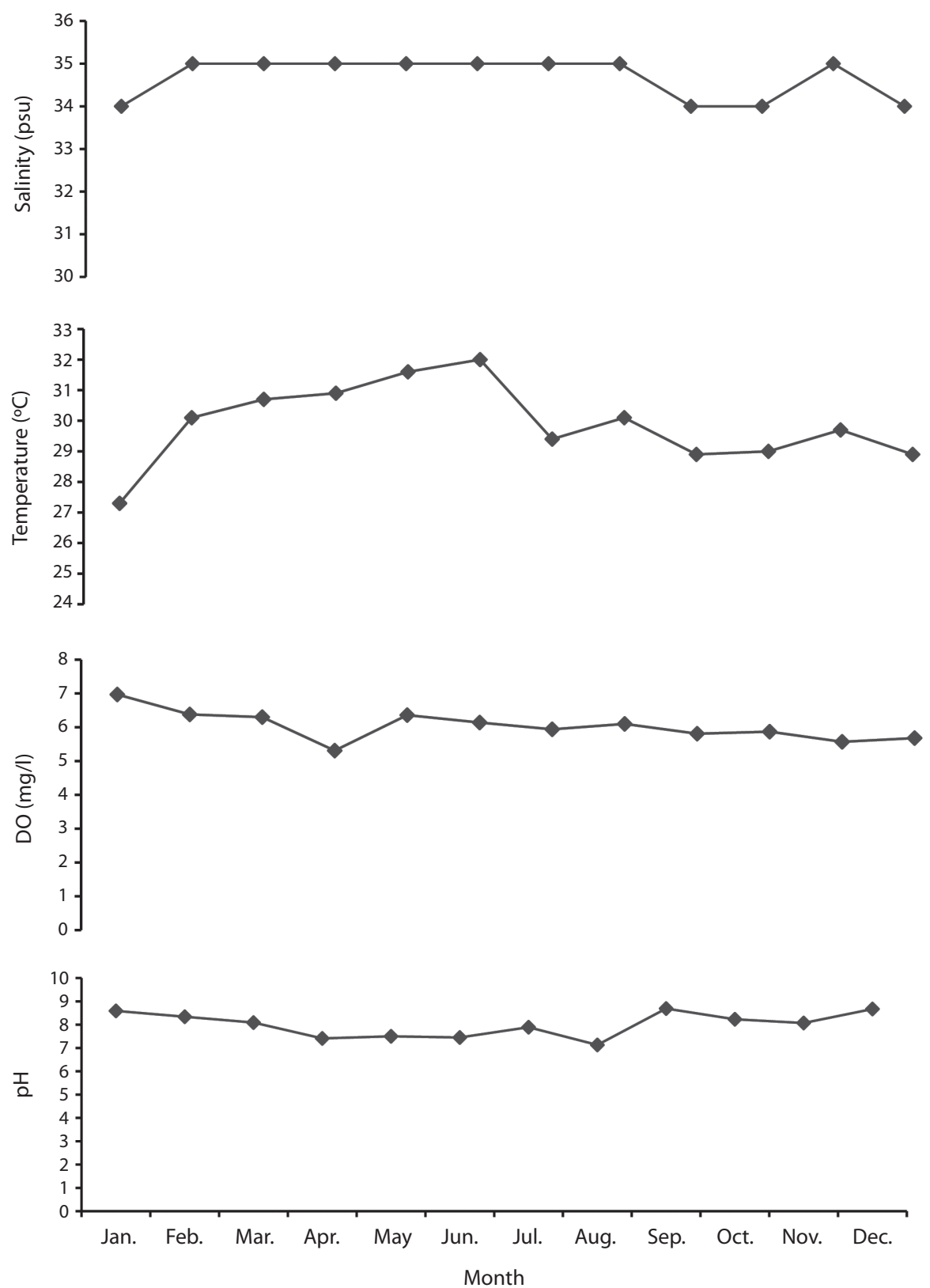

Fig. 7. Monthly variations in water temperature $\left({ }^{\circ} \mathrm{C}\right)$, salinity $(\mathrm{psu})$, dissolved oxygen $(\mathrm{mg} / \mathrm{L})$ and $\mathrm{pH}$ in the collecting site from January to December 2010.

The presence of gonads in developing, mature and spawning stages in all months of the year may suggest that gametogenesis, maturation and spawning of L. philippinarum occur throughout the year. This is supported by the mean GI values of L. philippinarum which ranged from 2.2-2.6 suggesting that most of the clams were undergoing maturation. However it was observed in this study that though developing, mature and spawning occur throughout the 
year, there was high percentage of spawning gonads in January and June which may suggest a spawning peak. This could be related to the increase and decrease in water temperature (ANOVA, $\mathrm{p}<0.05$ ). An increase of $5^{\circ} \mathrm{C}$ of water temperature, from $27^{\circ} \mathrm{C}$ in January- $32^{\circ} \mathrm{C}$ in June could have triggered the spawning of the clam which peaked in June, respectively. Similarly, the decrease of $3.1^{\circ} \mathrm{C}$, from $32^{\circ} \mathrm{C}$ in June to $28.9^{\circ} \mathrm{C}$ in December might made it possible for most gonads to mature that resulted to another spawning peak in January. Changes in water temperatures have also been observed to influence the spawning of both Pinctada fucata and Pinctada margaritifera in Taiwan (Hwang 2007). The first spawning peak of $P$. fucata was associated with rising water temperature from April to May and second spawning occurred when water temperature decreased from September to October. P. margaritifera has been observed to spawn when the water temperature increased. Changes in water temperature were also observed to trigger Lima scabra to mass spawn (Lodeiros \& Himmelman 1999).

For spent and resting stages of L. philippinarum, results of this study may suggest that the duration of these stages were short thus the clam was already in the next gonad stage when the next monthly sampling was conducted. According to Campos \& Campos (2010) tropical species usually redevelop new gametes right after spawning with hardly inactive phase such as spent stage. In their study of Paphia undulata from Negros Occidental, Philippines, a similar situation in L. philippinarum was observed in which there were only few individuals of $P$. undulata with spent gonads.

\section{Notes on the fishery of snout otter clam} in the Philippines: The calculated CPUE showed that among the collecting sites, Manjuyod has still more wild stocks. However, compared to other commercially important clams such as $P$. undulata in Negros Occidental, Philippines, (Agasen et al. 1998), Meretrix costa, Paphia malabarica and Villorita cyprinoids in Malabar, India (Laxmilatha et al. 2007), the L. philippinarum CPUE was lower.
The catch rate of $P$. undulata ranged from $51 \mathrm{~kg} /$ boat to $215 \mathrm{~kg} /$ boat, Meretrix costa was at $125 \mathrm{~kg} / \mathrm{hr}-\mathrm{man}$, Paphia malabarica was at $22 \mathrm{~kg} / \mathrm{hr}-\mathrm{man}$ and Villorita cyprinoids at $123 \mathrm{~kg} /$ hr-man and which were all higher than $1.25 \mathrm{~kg} /$ hr-man of L. philippinarum.

A low CPUE value would mean low relative abundance of an organism (Luchavez \& Abrenica 1997). Although there are several factors that could be attributed to the decline of fishable biomass, the daily harvesting of $L$. philippinarum observed in the collecting sites during this study showed that massive exploitation is one of the main factors in population decline resulting to low catch.

Decline in the population of L. philippinarum prompted the collectors to divert their collection on other bivalve species still dominant in the area as observed in Cordova, Cebu. A similar situation was observed in Sorsogon Bay, Philippines when the catch of $P$. undulata declined in 1987 (Agasen et al. 1998). Furthermore, there were reports in Negros Oriental that the size of $L$. philippinarum in most of their harvests decreased and specific collection site is getting farther from the shore as compared 5-10 years ago. Bigger shells contributed largely to the total reproductive output and the massive collections of these shells can dwindle the population size of the species (Boer et al. 2000). In Strombus urceus and Strombus labiatus in Eastern Samar, Philippines (Ciasico et al. 2006), Anadara tuberculosa in Purruja, Costa Rica (Pirlot \& Wolff 2006) and P. undulata in Negros Occidental, Philippines (Campos \& Campos 2010), a decrease in their shell size indicates a worsening of the status of the bivalve fishery in the country.

Thus to have sustainable supply of $L$. philippinarum in the Philippines, it is recommended that proportion of mature individuals be left in the population to allow in situ breeding to take place. A useful minimum size limit is above $43 \mathrm{~mm}-46 \mathrm{~mm}$ which is the size at sexual maturity of $L$. philippinarum. The clams below this size range should be left undisturbed to guarantee recruitment in the area. 


\section{ACKNOWLEDGMENTS}

The authors are grateful to the Department of Science and Technology-Philippine Council for Marine and Aquatic Research and Development (DOST-PCAMRD) for funding this study.

\section{RESUMEN}

Lutraria philippinarum es una especie de bivalvo recolectada regularmente para la alimentación y como fuente de ingreso en las Filipinas. Para el suministro sostenible de este recurso en la naturaleza, se necesitan estrategias de manejo efectivas, así como la evaluación de su biología reproductiva y pesquera. Se examinaron estos aspectos mensualmente de enero-diciembre 2010 en North Bais Bay, Manjuyod, Negros Oriental, Filipinas. Se tomó medida del tamaño a la madurez sexual, proporción de sexos (con observación microscópica), longitud de la concha (con calibrador vernier), desarrollo de gónadas (con examinación histológica del descanso, desarrollo, madurez, desove y gasto) y época de desove. Para obtener información de la pesquería de L. philippinarum, se realizaron entrevistas en Negros Oriental, Bohol, Cebu y Sarangani. Un total de 677 ostras fueron muestreadas. Se encontró que la proporción de sexos fue 1:1.15 y no se observó diferencia significativa de la proporción 1:1. Los machos alcanzaron la madurez sexual a la longitud de concha de $43 \mathrm{~mm}$ mientras que las hembras a $46 \mathrm{~mm}$. El análisis histológico del desarrollo de las gónodas indicó que la gametogénesis, maduración y desove ocurren durante todo el año con dos picos de desove, enero y junio. Los datos sobre la pesquería revelaron que la captura por unidad de esfuerzo de L. philippinarum osciló entre $0.2 \mathrm{~kg} / \mathrm{h}$ hombre a $1.25 \mathrm{~kg} / \mathrm{h}$ hombre que sugieren baja captura de conchas. Recomendamos que algunos individuos maduros tienen que ser dejados en la población para permitir la reproducción in situ.

Palabras clave: Lutraria philippinarum, madurez sexual, desove, proporción de sexos, pesca.

\section{REFERENCES}

Agasen, E., A. del Mundo \& G. Matias. 1998. Assessment of Paphia undulata in Negros Occidental/Guimaras Strait waters. J. Shellfish. Res. 17: 1613-1617.

Boer, W., T. Pereira \& A. Guissamulo. 2000. Comparing recent and abandoned shell midden to detect the impact human exploitation on the intertidal ecosystem. Aqua. Ecol. 34: 287-297.
Campos, A. \& W. Campos. 2010. Managing the nylon shell (Paphia undulata) fishery off Negros Occidental. University of the Philippines, Miagao, Iloilo, Philippines.

Ciasico, M., E. Villaluz, P. Geraldino, D. Dy \& A. Diola. 2006. Initial stock assessment of four Strombus species (Mollusca: Gastropoda) in Eastern Samar (Central Philippines) with notes on their fishery. Phil. Sci. 43: 52-68.

Gosling, E. 2003. Bivalve mollucs biology ecology and culture. Blackwell, Oxford, United Kingdom.

Ha Duc Dang, Ha Dinh Thuy \& Nguyen Xuan Doc. 2006. Initial result of the research on artificial seed production of Lutraria philippinarum. (Downloaded: July 19, 2009, www.fistenet.gov.vn.).

Hightower, E. \& G. Grossman. 1985. The relative gonadal: An alternative index for quantification of reproductive condition. Comp. Biochem. Physiol. A Comp. Physiol. 81: 117-20.

Honkoop, P., J. Van der Meer, J. Beukema \& D. Kwast. 1999. Reproductive investment in the intertidal bivalve Macoma balthica. J. Sea Res. 41: 203-212.

Hwang, J. 2007. Reproductive cycles of the pearl oysters, Pinctada fucata (Gould) and Pinctada margaritife$r a$ (Linnaeus) (Bivalvia:Pteriidae) in Southwestern Taiwan waters. J. Mar. Sci. Technol. 15: 67-75.

Ilano, A., K. Fujinaga \& S. Nakao. 2003. Reproductive cycle and size at sexual maturity of the commercial whelk Buccinum isaotakii in Funka Bay, Hokkaido, Japan. J. Mar. Biol. Ass. U.K. 83: 1287-1294.

Ilano, A., F. Sotto \& J. Juario. 2007. Sexual maturity and reproductive cycle of Paphia textilis (Gmelin, 1971) (Bivalvia:Veneroidea) off Sillon waters, Bantayan Island, Cebu, Philippines. J. Aqua. Sci. 4: 89-103.

Laxmilatha, P., M. Sivadasan \& V. Surendranath. 2007. Bivalve resources and its exploitation in Malabar. Mar. Fish. Inf. Tech. Ext. Ser. 192.

Lodeiros, C. \& J. Himmelman. 1999. Reproductive cycle of the bivalve Lima scabra (Pteroida: Limidae) and its association with environmental conditions. Rev. Biol. Trop. 47: 1-15.

Luchavez, J. \& B. Abrenica. 1997. Fisheries profile of Bais Bay, Negros Oriental. Silli. J. 37: 93-137.

Mzighani, S. 2005. Fecundity and population structure of cockles, Anadara antiquata L.1758 (Bivalvia: Arcidae) from sandy/muddy beach near Dares Salaam, Tanzania. Indian J. Mar. Sci. 4: 77-84.

Pirlot, A. \& M. Wolff. 2006. Population dynamics and fisheries potential of Anadara tuberculosa (Bivalvia: Arcidae) along the Pacific coast of Costa Rica. Rev. Biol. Trop. 54: 87-99. 


\section{APPENDIX}

SURVEY QUESTIONNAIRE

Date:

Name of the Collector:

Local Name of Lutraria philippinarum:

Gleaning/Fishing operation: Fishing hours: Number of hours/ trip:

No. of trips/day: Total catch/trip: Income/trip:

No of collecting days:

Number of persons required per gleaning/ fishing operations:

Method of collection:

Gleaning/Fishing ground:

Depth of the gleaning/fishing ground:

\section{Questions:}

What do you do with the clams collected? Home consumption Sold, If sold, to whom and how much? middlemen , Price (per kilo/piece/container)

local market , Price

street selling , Price

outside barangays , Price

2. Who sold the clams? 